\title{
Editorial
}

\section{Catalysts for Syngas Production}

\author{
Javier Ereña \\ Department of Chemical Engineering, University of the Basque Country UPV/EHU, P.O. Box 644, \\ 48080 Bilbao, Spain; javier.erena@ehu.eus; Tel.: +34-94-6015363
}

Received: 8 June 2020; Accepted: 10 June 2020; Published: 11 June 2020

Synthesis gas (or syngas) is a mixture of hydrogen and carbon monoxide, that may be obtained from alternative sources to oil, such as natural gas, coal, biomass, organic wastes, etc. [1-3] Biomass is a promising raw material for syngas production, due to its renewable character and potentially zero $\mathrm{CO}_{2}$ emissions [4]. Syngas is an excellent intermediate for the production of high value compounds at the industrial scale, such as hydrogen, methanol, liquid fuels, and a wide range of chemicals.

This Special Issue on "Catalysts for Syngas Production" shows new research about the development of catalysts and catalytic routes for syngas production, and the optimization of the reaction conditions for the process.

This issue includes ten articles. Yu et al. analyze the performance of Ni-Co bi-metallic catalysts in n-decane steam reforming [5]. The addition of Co to the catalyst improves the hydrogen selectivity and anti-coking ability compared with the mono-Ni/Ce- $\mathrm{Al}_{2} \mathrm{O}_{3}$ catalyst. A synergistic effect between $\mathrm{Ni}$ and $\mathrm{Co}$ is observed, with $12 \%$ Co showing the best catalytic activity in the series Co-Ni/Ce- $\mathrm{Al}_{2} \mathrm{O}_{3}$ catalysts. In situ regeneration of a spent alumina-supported cobalt-iron catalyst for catalytic methane decomposition is reported by Fakeeha et al. [6] The main factors responsible for the catalyst deactivation are coke deposition and weak sintering of the metallic active phase ( $\mathrm{Co}-\mathrm{Fe})$, which occur during the catalytic methane decomposition reaction and regeneration process. A facile fabrication of supported $\mathrm{Ni} / \mathrm{SiO}_{2}$ catalysts for dry reforming of methane is developed by Xu et al. [7] Due to the formation of much smaller Ni nanoparticles, this $\mathrm{Ni} / \mathrm{SiO}_{2}$ catalyst exhibits excellent coke-resistance performance and effectively suppresses the side reaction toward RWGS compared to that prepared with the conventional wetness impregnation method. The dry reforming of methane over combined magnesia, ceria and nickel catalysts, supported on $\gamma-\mathrm{Al}_{2} \mathrm{O}_{3}$ and doped with $\mathrm{TiO}_{2}$, is investigated by Al-Fatesh et al. [8] The addition of $\mathrm{CeO}_{2}$ and $\mathrm{MgO}$ to the catalyst enhances the interaction between the Ni and the support, and improves the activity of the solid. Liu et al. describe a novel one-step conversion of $\mathrm{CO}_{2}$ and $\mathrm{H}_{2} \mathrm{~S}$ to syngas induced by non-thermal plasma, with the aid of Ni-Mo sulfide $/ \mathrm{Al}_{2} \mathrm{O}_{3}$ catalyst under ambient conditions [9]. The optical and structural properties of the synthesized catalysts are significantly influenced by the Ni/Mo molar ratio. Moreover, the Ni-Mo sulfide $/ \mathrm{Al}_{2} \mathrm{O}_{3}$ catalysts possess excellent catalytic activities for $\mathrm{CO}_{2}$ and $\mathrm{H}_{2} \mathrm{~S}$ conversion, compared to the single-component $\mathrm{NiS}_{2} / \mathrm{Al}_{2} \mathrm{O}_{3}$ and $\mathrm{MoS}_{2} / \mathrm{Al}_{2} \mathrm{O}_{3}$ catalysts. The paper by Park et al. describes the effect that reaction parameters have on hydrogen production via steam reforming of methane, using lab- and bench-scale reactors to identify critical factors for the design of large-scale processes [10]. The temperature at the reactor bottom is crucial for determining the methane conversion and hydrogen production rates when a sufficiently high reaction temperature is maintained (above $800^{\circ} \mathrm{C}$ ). However, if the temperature of one or more of the furnaces decreases below $700{ }^{\circ} \mathrm{C}$, the reaction is not equilibrated at the given space velocity. Liu et al. study a novel sulfur tolerant water gas shift catalyst (SWGS) developed for the applications under lean (low) steam/gas ratio conditions [11]. The adoption of the lean steam/gas SWGS catalyst significantly improves the plant efficiency and safety, and remarkably reduces the actual steam consumption for $\mathrm{H}_{2}$ production, decreasing $\mathrm{CO}_{2}$ emission. The paper by Fasolini et al. summarizes the synthesis, characterization and catalytic behavior of Rh-based catalysts, obtained by using the 
$\mathrm{Rh}_{4}(\mathrm{CO})_{12}$ neutral cluster as the active-phase precursor [12]. The preparation method allows the deposition of the cluster on the surface of $\mathrm{Ce}_{0.5} \mathrm{Zr}_{0.5} \mathrm{O}_{2}$ and $\mathrm{ZrO}_{2}$ supports, which are synthetized by the microemulsion technique, being the catalysts active in the low-temperature steam reforming process for syngas production. Methane and ethane steam reforming over $\mathrm{MgAl}_{2} \mathrm{O}_{4}$-supported $\mathrm{Rh}$ and Ir catalysts is analyzed in the paper by Lopez et al. [13] The Rh- and Ir-supported catalysts exhibit higher activity than $\mathrm{Ni}$ catalysts for steam methane reforming. Catalyst durability studies reveal the Rh catalyst to be stable under steam methane reforming conditions. The results of this study conclude that a Rh-supported catalyst enables very high activity and excellent stability, for both the steam reforming of methane and other higher hydrocarbons contained in natural gas, and under conditions of operation that are amendable to solar thermochemical operations. In the paper by Azara et al., iron-rich mining residue is used as a support to prepare a new Ni-based catalyst for $\mathrm{C}_{2} \mathrm{H}_{4}$ dry reforming and catalytic cracking [14]. The deposited carbon is found to be filamentous and of various sizes (i.e., diameters and lengths). The analyses of the results show that iron is responsible for the growth of carbon nanofilaments and nickel is responsible for the split of C-C bonds.

In summary, these ten papers clearly show the relevance of obtaining syngas for further applications, such as the production of hydrogen, methanol, liquid fuels, and a wide range of chemicals. Nowadays, efforts are being made on the co-feeding of $\mathrm{CO}_{2}$ with syngas, as an alternative for reducing greenhouse gas emissions. I would like to thank all the authors of this Special Issue.

I am honored to be the Guest Editor of this Special Issue. I would like to thank the reviewers for improving the quality of the papers with their comments. I am also grateful to all the staff of the Catalysts Editorial Office.

Conflicts of Interest: The authors declare no conflict of interest.

\section{References}

1. Gao, J.; Guo, J.; Liang, D.; Hou, Z.; Fei, J.; Zheng, X. Production of Syngas via Autothermal Reforming of Methane in a Fluidized-bed Reactor over the Combined $\mathrm{CeO}_{2}-\mathrm{ZrO}_{2} / \mathrm{SiO}_{2}$ Supported Ni Catalysts. Int. J. Hydrog. Energy 2008, 33, 5493-5500. [CrossRef]

2. Rezaei, M.; Alavi, S.M.; Sahebdelfar, S.; Yan, Z.F. Syngas Production by Methane Reforming with Carbon Dioxide on Noble Metal Catalysts. J. Nat. Gas Chem. 2006, 15, 327-334. [CrossRef]

3. He, M.; Xiao, B.; Liu, S.; Hu, Z.; Guo, X.; Luo, S.; Yang, F. Syngas Production from Pyrolysis of Municipal Solid Waste (MSW) with Dolomite as Downstream Catalysts. J. Anal. Appl. Pyrolysis 2010, 87, 181-187. [CrossRef]

4. Molino, A.; Chianese, A.; Musmarra, D. Biomass Gasification Technology: The State of the Art Overview. J. Energy Chem. 2016, 25, 10-25. [CrossRef]

5. Yu, Q.; Jiao, Y.; Wang, W.; Du, Y.; Li, C.; Yang, J.; Lu, J. Catalytic Performance and Characterization of Ni-Co Bi-Metallic Catalysts in n-Decane Steam Reforming: Effects of Co Addition. Catalysts 2018, 8, 518. [CrossRef]

6. Fakeeha, A.H.; Barama, S.; Ibrahim, A.A.; Al-Otaibi, R.L.; Barama, A.; Abasaeed, A.E.; Al-Fatesh, A.S. In Situ Regeneration of Alumina-Supported Cobalt-Iron Catalysts for Hydrogen Production by Catalytic Methane Decomposition. Catalysts 2018, 8, 567. [CrossRef]

7. Xu, Y.; Lin, Q.; Liu, B.; Jiang, F.; Xu, Y.; Liu, X. A Facile Fabrication of Supported Ni/SiO ${ }_{2}$ Catalysts for Dry Reforming of Methane with Remarkably Enhanced Catalytic Performance. Catalysts 2019, 9, 183. [CrossRef]

8. Al-Fatesh, A.S.; Kasim, S.O.; Ibrahim, A.A.; Fakeeha, A.H.; Abasaeed, A.E.; Alrasheed, R.; Ashamari, R.; Bagabas, A. Combined Magnesia, Ceria and Nickel Catalyst Supported over $\gamma$-Alumina Doped with Titania for Dry Reforming of Methane. Catalysts 2019, 9, 188. [CrossRef]

9. Liu, X.; Zhao, L.; Li, Y.; Fang, K.; Wu, M. Ni-Mo Sulfide Semiconductor Catalyst with High Catalytic Activity for One-Step Conversion of $\mathrm{CO}_{2}$ and $\mathrm{H}_{2} \mathrm{~S}$ to Syngas in Non-Thermal Plasma. Catalysts 2019, 9, 525. [CrossRef]

10. Park, H.G.; Han, S.Y.; Jun, K.W.; Woo, Y.; Park, M.J.; Kim, S.K. Bench-Scale Steam Reforming of Methane for Hydrogen Production. Catalysts 2019, 9, 615. [CrossRef] 
11. Liu, B.; Zhao, L.; Wu, Z.; Zhang, J.; Zong, Q.; Almegren, H.; Wei, F.; Zhang, X.; Zhao, Z.; Gao, J.; et al. Recent Advances in Industrial Sulfur Tolerant Water Gas Shift Catalysts for Syngas Hydrogen Enrichment: Application of Lean (Low) Steam/Gas Ratio. Catalysts 2019, 9, 772. [CrossRef]

12. Fasolini, A.; Ruggieri, S.; Femoni, C.; Basile, F. Highly Active Catalysts Based on the $\operatorname{Rh}_{4}(\mathrm{CO})_{12} \mathrm{Cluster}$ Supported on $\mathrm{Ce}_{0.5} \mathrm{Zr}_{0.5}$ and $\mathrm{Zr}$ Oxides for Low-Temperature Methane Steam Reforming. Catalysts 2019, 9, 800. [CrossRef]

13. Lopez, J.S.; Dagle, V.L.; Deshmane, C.A.; Kovarik, L.; Wegeng, R.S.; Dagle, R.A. Methane and Ethane Steam Reforming over $\mathrm{MgAl}_{2} \mathrm{O}_{4}$-Supported $\mathrm{Rh}$ and Ir Catalysts: Catalytic Implications for Natural Gas Reforming Application. Catalysts 2019, 9, 801. [CrossRef]

14. Azara, A.; Benyoussef, E.H.; Mohellebi, F.; Chamoumi, M.; Gitzhofer, F.; Abatzoglou, N. Catalytic Dry Reforming and Cracking of Ethylene for Carbon Nanofilaments and Hydrogen Production Using a Catalyst Derived from a Mining Residue. Catalysts 2019, 9, 1069. [CrossRef]

C 2020 by the author. Licensee MDPI, Basel, Switzerland. This article is an open access article distributed under the terms and conditions of the Creative Commons Attribution (CC BY) license (http://creativecommons.org/licenses/by/4.0/). 